\title{
How to understand and help a person with borderline personality. Case report and literature review on the therapeutic possibilities
}

Zrozumieć i pomóc osobie z osobowością chwiejną emocjonalnie. Opis przypadku i przegląd literatury dotyczącej możliwości terapeutycznych

Elżbieta Sitarz ${ }^{1}$ ABDEF, https://orcid.org/0000-0001-7503-1838, Iga Dudek² DEF, https://orcid.org/0000-0002-8101-074X, Kaja Karakuła³ ABDEF, https://orcid.org/0000-0003-1493-8502,

\author{
Alicja Forma² ABDEF, https://orcid.org/0000-0001-8714-7627, \\ Dariusz Juchnowicz ${ }^{4}$ ABDEF, https://orcid.org/0000-0003-2027-5469
}

${ }^{1}$ I Department of Psychiatry, Psychotherapy, and Early Intervention, Medical University of Lublin, Poland

${ }^{2}$ Student Research Group Department of Forensic Medicine, Medical University of Lublin, Poland

${ }^{3}$ Psychiatry Student Research Group I Department of Psychiatry, Psychotherapy and Early Intervention, Medical University of Lublin

${ }^{4}$ Department of Psychiatric Nursing, Medical University of Lublin

\begin{abstract}
Introduction: The study aims to present 1) a case report of an 18-year-old female patient with borderline personality disorder (BPD) 2) the diagnostic and treatment difficulties in BPD patients.

Materials and methods: The review of the literature from the years 1953-2020 searched from PubMed, Google Scholar, and Web of Science databases.

Discussion: Patient, 18-years old, hospitalized five times for psychiatric care, presenting self-injurious behaviours, hurting herself within forearms. A patient attempted suicide eight times. She is living with her divorced parents. The patient's father has a new partner with whom he has children. The patient used marijuana and she was experiencing psychotic symptoms under its influence. She smokes 10 cigarettes per day and drinks alcohol once a week since she was 16 years old. Psychiatric problems appeared when the patient started learning in high school.

Conclusions:

1. Borderline personality disorder (BPD) is a serious psychiatric condition of a difficult diagnosis that should be differentiated with many other psychiatric disorders such as an atypical or subclinical course of psychosis, affective disorders, or dissocial personality.

2. A therapeutic process of a person with BPD is based on psychotherapy and personalized treatment strategies, whereas, pharmacological treatment plays only a supporting role during BPD treatment.
\end{abstract}

Keywords: borderline, personality disorder, diagnosis

\author{
Streszczenie \\ Wstęp: Celem pracy jest 1) przedstawienie opisu przypadku 18-letniej pacjentki z rozpoznaniem zaburzenia osobowości typu \\ borderline 2) przedstawienie trudności w diagnostyce i leczeniu chorych z tym zaburzeniem. \\ Materiał i metoda: Przegląd piśmiennictwa z lat 1953-2020 korzystając z bazy danych PubMed, Google Scholar oraz Web of \\ Science. \\ Dyskusja: Pacjentka, lat 18, pięciokrotnie hospitalizowana psychiatrycznie, wielokrotnie dokonująca samookaleczeń w obrębie \\ obu przedramion. Podjęła osiem prób samobójczych. Mieszka z rodzicami, którzy są po rozwodzie. Ojciec pacjentki ma nową \\ partnerkę, z którą ma dzieci. Pacjentka podaje kilkukrotne stosowanie marihuany, pod wpływem której doświadczała objawów \\ psychotycznych. Pali około 10 papierosów dziennie oraz spożywa alkohol średnio raz w tygodniu począwszy od 16 roku \\ życia. W szkole podstawowej i gimnazjum była wzorową uczennicą i osiągała bardzo dobre wyniki w nauce. Problemy natury \\ psychicznej pacjentka zaczęła przejawiać wraz z pójściem do liceum.
}


Wnioski:

1. Borderline personality disorder (BPD) to zaburzenie psychiczne o trudnej diagnostyce, którą należy różnicować z wieloma zaburzeniami psychicznymi - nietypowym lub subklinicznym przebiegiem psychozy, zaburzeniami afektywnymi oraz osobowością dyssocjalną.

2. Proces terapeutyczny osoby z zaburzeniem osobowości typu borderline opiera się głównie na psychoterapii i personalizacji leczenia, przy czym leczenie farmakologiczne odgrywa wyłącznie rolę wspierającą.

Słowa kluczowe: borderline, zaburzenia osobowości, diagnostyka

\section{Introduction}

Borderline personality disorder (BPD) is a serious psychiatric disorder that is characterized by unstable self-perception, affect lability, repeated self-destructive behaviours, as well as difficulties in establishing interpersonal relations [1]. Epidemiological data indicate that a problem of BPD concerns approximately $1.7 \%$ of the society and it is diagnosed in $15-28 \%$ of patients from psychiatric clinics and hospitals [2]. The risk of BPD development is estimated at $5.9 \%$ throughout the whole life $[3,4]$. It is diagnosed with a similar prevalence in both females and males [3]. BPD is also associated with a high grade physical and mental disabilities, primarily among young females.

The term 'borderline state' was used for the first time in a study published by Robert Knight in 1953 [5]. A term concerned those patients who could not be completely diagnosed as psychotic or neurotic but were presenting characteristics that are typical for both of the abovementioned types of disorders. In 1978 seven characteristics (discriminating criteria) were distinguished in patients who were described as 'borderline patients' and those included little achievement and lack of motivation, impulsiveness, often suicide thoughts, increased emotionality, mild psychotic episodes, and the willingness for socialization at the same time presenting disrupted interpersonal relations [6]. The abovementioned publication has become a pillar of the first official criteria by the American Psychiatric Association DSM-III that enable the diagnosis of BPD. Currently used tools to diagnose BPD are ICD-10 criteria and amended DSM-V criteria from 2013. ICD10 distinguishes two subtypes of emotionally unstable personality (F 60.3) - borderline and impulsive types [7]. DSM-V classification does not include the differentiation of personality disorders into particular subtypes [8]. ICD-11 proposed the differentiation of personality disorders in terms of their severity into mild, moderate, or severe [9].

BPD is associated with nearly ten times higher rate of mortality due to suicide compared to the general population [10]. One of the major characteristics of BPD is the presence of chronic suicidal thoughts [11]. In patients with mood disorders, suicidal thoughts usually disappear after the remission of the disorder. Patients with BPD might consider suicide for many months or even years and those thoughts might be intensified during stressful life events. BPD usually coexists with other psychiatric conditions such as anxiety disorders, which are associated with an even higher risk of suicide in such patients [12].

The etiology of BPD is not completely understood yet, thus, its definition has been changed many times. It is believed that the development of BPD is associated with the interaction between genetic and environmental factors [13]. The results of the studies performed on the twins confirm the role of the genetic factors and the inheritance of BPD is estimated at $40 \%$. Moreover, there is an increasing interest related to the genetic alterations within the hypothalamic-pituitary-adrenal axis (HPA) which is responsible for the psychological and psychophysiological stress reaction. It was shown that in patients with BPD, the polymorphism of the FKBP5 gene is quite common; this gene encodes the protein that is involved in the processes that regulate glucocorticoid receptors, which ultimately has an impact on the HPA dysfunctions [14,15]. BPD usually coexists with alcohol use disorder and an excessive alcohol intake additionally induces changes within the central and peripheral nervous systems [16-19]. Among environmental factors that are crucial in the pathogenesis of BPD, physical abuse of children, sexual abuse, or negligence in childhood are usually mentioned [20-23]. Besides, low upbringing level, aversive parental behaviours, or being a witness of home abuse against a partner, are of high importance [24,25]. Another interesting aspect is the presence of changes that occur within the central nervous system that is observed in patients with diagnosed BPD and those include the bilateral loss of the grey matter of the orbitofrontal cortex or the alterations within the neuronal prefrontal-limbic connections that disrupt the modulations in the structures of the limbic system through the frontal cortex [26-28].

The main treatment strategies are cognitivebehavioral therapy and psychodynamic therapy, as well as schema therapy and relocation-based therapy. Additional pharmacological treatment might include antipsychotic drugs, antidepressants, or mood stabilizers. Currently, there is more evidence that confirms the effectiveness of psychotherapy compared to pharmacotherapy. The main aim of the treatment is the improvement of social 
functioning. However, this aim is very hard to achieve and constitutes a great challenge for clinicians.

\section{Case report}

Patient, 18-years old, childless, a 3rd-grade student of the Secondary School, hospitalized five times for psychiatric care. The first hospitalization was due to the depressed mood and lowered psychomotor drive, changed behaviour, exasperation, incidents of the verbal aggression, and loss of appetite which were the consequences of the traumatic situation that occurred in the peer environment. The patient was initially discharged from the hospital being diagnosed with the reaction to severe stress (F 43.2). Another admission to the psychiatric ward was reported several months later because of the attempted suicide of the patient through the administration of several paroxetine pills; afterwards, she was discharged from the hospital with the specific personality disorder (F 60.0) diagnosed. During other hospitalizations due to further suicide attempts, the patient was diagnosed with F 60.8 - an incorrectly shaped personality. The final diagnosis was F 60.3 - emotionally unstable personality.

According to the medical interview towards the usage of psychoactive substances and addictions, the patient claimed that she has used marijuana several times and when she was under its influence, she was experiencing psychotic symptoms by the expression of the persecution delusions. She claimed that she smokes approximately 10 cigarettes per day and drinks alcohol once a week since she was 16-years old.

The perinatal review - the patient was born in the 27th week of pregnancy due to the severe bleeding from the genital tract of a mother, birth weight equal to 1100 grams. According to Apgar's scale, the score in the first minute was equal to 5 points because of the lack of reflexes, inappropriate skin colour and muscle tension, in the third minute the score was equal to 7 points. Early childhood development was appropriate.

The family history towards psychiatric disorders includes the diagnosed depression in a second-degree relative.

\section{Reasons for hospitalization}

The reason for the patient's hospitalization was an increased number of suicidal contents spoken by the patient, self-destructive behaviours, psychomotor agitation, impulsiveness, incidents of insomnia, and aggressive behaviours. The patient was expressing a lot of vulgarisms, usually of a sexual nature and threats towards the hospital personnel.

\section{Family situation}

The patient lives in her family house in the countryside with her parents and two younger siblings. The relationship with both patient's mother and father is described by the patient as inappropriate and not meeting her expectations. In individual interviews, reluctance towards both parents has appeared many times. The patient's sister is during adolescence, causes behavioral problems in a form of oppositional and rebellious behaviours, and is currently under the supervision of a curator. The patient's brother is submissive to both of their parents. The patient describes the relationship with her siblings as very good, however, during hospitalization, there were reasons to believe that she was competing with her younger sister for her parents' attention. The relations between younger brother and sister were described by the patient as correct, while the relations between the parents and younger siblings as complicated.

The patient's father has his own business activity and her mother keeps house. The patient's parents are divorced however, they still live together. The father's new partner is the sister of the patient's mother, with whom he also has children and with whom both the patient and her younger siblings maintain contacts. From the medical interview, it can be concluded that the patient's parents use corporal punishment in all of the children. According to her parents, a noticeable change in the patient's behaviour was observed one year ago. Previous behaviours did not raise any objections.

The patient was gradually retreating from the activities that were previously giving her pleasure, she stopped being involved in the school ventures, and other activities outside the school. She was gradually becoming more vulgar, aggressive, and she started to mutilate herself, primarily within the forearms. At the same time, she also started smoking cigarettes, drinking alcohol, and experimenting with psychoactive substances; being under the influence of such substances, the patient was experiencing psychotic symptoms - persecution delusions. An abrupt change in the patient's behaviour for more aggressive was also associated with the incidence of a traumatic event in the peer environment - the patient's friend from her class committed suicide. The patient claims that she attempted suicide eight times. The last attempt (11th September 2019) was due to the administration of several paroxetine pills. Several months after a change in the patient's behaviour, she was psychiatrically consulted on an outpatient basis. The psychotherapist was taking care of her, however, the patient did not want to collaborate with him, showing passive resistance. After a few sessions, she stopped the therapy.

\section{School situation:}

The patient is a 3rd class student in the Secondary 
School. In the primary school and junior high school, she was adapting properly, was an exemplary schoolgirl who was actively involved in the school community by the organization of many different ventures and projects. During her education, she never repeated her grade. The problems were gradually appearing at the same time the patient went to high school. In high school, the patient was getting satisfactory grades and she was not making new friends there. Her relations were limited only to three persons whom she knew from primary school. As time passed, the patient presented aggressive behaviours that were inducing conflicts with her parents, teachers, and peers. She started skipping classes and smoking marijuana. She was spending her free time with her siblings and friends who (according to the collected interview) were presenting a tendency for neglecting the social and moral rules.

\section{Psychological examination}

The Minnesota Multidimensional Personality Inventory - 2 (MMPI-2) was published in 1943 by dr Starke Hathway and J. Charnley McKinley and it still remains the most popular questionnaire method of personality testing [29].

During hospitalization the patient was examined with the Personality Inventory. Analysis of the control scales L (43T), F (46T), Fb (94), Fp (70), FBS (69T), K (82T), indicates that the patient exaggerates her experienced psychopathological symptoms which etiology the patient is not aware of. The profile of clinical scales D (76T), Sc (79T), Pd (75T), Hy (66T) is significantly increased. In the clinical profiles, Sc (79T) scale obtained the highest score which suggests that the patient's well-being is primarily composed of emotions associated with anxiety, fear, and tension. It is highly probable that the interpersonal isolation associated with the difficulties in establishing emotionally close dependency relationships was present. The patient shows the suspiciousness towards particular intentions during interpersonal relationships, besides, she is excessively sensitive and feels anxiety and fear of being rejected by others. She is especially characterized by the submissiveness and the feeling of being worse than others. Moreover, the patient experiences depressive moods D (76T), reveals a tendency to excessive worrying, and has a rumination of thoughts regarding past experiences; she also reveals the anxious vision of her past experiences. Based on the results of the Pd (75T) scale, it can be concluded that the patient has a tendency to impulsive behaviours and suppresses her emotions, for example - anger and aggression, as well as a rebellion towards authorities. Besides, the patient neglects the importance of the emotional difficulties she experiences and shows the lack of realism concerning the assessment of the situations that are experienced by her. Analysis of the results of the Hy (73T) scale shows that the patient is not able to perceive and understand the etiology and nature of her difficulties. It is also possible that the patient tends to react with somatic symptoms to unresolved psychological problems. Taken into consideration all of the above-mentioned aspects, the obtained clinical picture indicates the personality characteristics of experienced psychopathological symptoms with signs that are typical for bipolar personality disorder (BPD).

\section{Neurological consultation}

During the outpatient treatment, the patient was taking the following medicines: pregabalin, trazodone, venlafaxine, quetiapine, clorazepic acid, and perazine. During hospitalization, the patient refused to take all of the drugs even though she was informed by the doctor about the possible after-effects for her health and life. The patient experienced withdrawal syndrome in the form of anxiety, confusion, irritability, dizziness, and temporary disturbances of consciousness. Because of the abovementioned situation, the results of the first EEG examination were not reliable and could not be further interpreted. The next EEG recording was incorrect. The results showed generalized changes or changes that were limited to the temporal areas (due to hyperventilation) of the increasing severity - the changes occurred slightly more prevalently on the left side in a form of slow theta-delta waves or free or acute volleys of the paroxysmal character. The basic activity characterized by disorganization and a slight slowdown. MRI examination was regular. The neurologist recommended control in the neurological clinic and a control EEG examination within 6 months after the discharge of a patient from the ward.

\section{Hospitalization course}

During the first day of the patient's admission to the hospital, she was trying to commit suicide by hanging on the shoelaces. The attempted suicide failed thanks to the staff intervention against whom the patient was aggressive both orally and physically. In the ward the patient was initially not adapted in behaviour, she was impulsive, psychomotorally agitated, irritable, and depressed. She blamed the environment where she was living for the difficulties she had to experience, she was unhappy and felt misunderstood, she was continually talking about suicide. She tended to behave aggressively, even towards herself. She was hurting herself within the area of the left forearm; because of such behaviours she was immobilized for several times with the usage of the safety belts. She has broken the rules of the ward several times since she was smoking cigarettes in her room. However, with time, the cooperation with the patient was progressively 
improving. During the individual conversations with the patient, she started to maintain eye contact. Her verbal contact was factual and the content was poor. She started establishing proper peer relations, taking part in the meetings, physical and educational activities. Thanks to the individual as well as group psychotherapies, the improved functioning in the peer environment was obtained. The patient progressively started to perceive the nature of the difficulties she was struggling with. A great improvement of the mental health was obtained thanks to the psychotherapeutic interactions that were directed by the psychodynamic trend, as well as thanks to the introduction of the elements of the psychoanalytical psychotherapy. In order to maintain therapeutic success, it is crucial to continue the individual as well as family psychotherapies.

\section{Psychotherapy}

According to the results of scientific research, none of the therapeutic strategies of BPD treatment is considered to be the most effective. The symptoms and behaviours of the BPD patients are highly differentiated, therefore, the therapy should be chosen for a specific patient individually. According to Keefe et al. (2020), basing on the study performed on the 156 patients with BPD who were on the one-year dialectical-behavioral therapy and psychodynamic therapy, it was shown that individual characteristics and needs of a particular patient have an impact on the reaction of a patient to the specific therapy [30]. It was proved that further studies on the personalized treatment of BPD are needed.

Psychotherapy with a person with BPD is a very challenging task for a psychotherapist. Putrino et al. (2019) observed that psychotherapists might feel the changing emotions of patients with BPD [31]. Therapists might reflect the inner experiences of their patients therefore, they must be aware of their emotional reactions since it might affect the relation with a patient and further results of the therapy. Thus, it is recommended for psychotherapists to train their mindfulness, since it might be a good tool to improve one's self-regulation instead of avoidance or excessive identification with the emotional pain of patients.

Based on the results of a meta-analysis 'Effect of Psychotherapy for Borderline Personality Disorder on Quality of Life', which included 1370 patients with BPD and the mean age was 31.2 years old and $86.8 \%$ of the patients were females, Chakhssi et al. (2019) showed effectiveness of the following psychotherapies - dialectical behavioral therapy (DBT; $n=4)$, mentalization-based therapy (MBT; $n=3$ ), a system of training of emotional prediction and problem-solving systems (STEPPS; $\mathrm{n}=$ 2), and in other five studies - cognitive therapy (CT), cognitive-behavioral therapy (CBT), emotional regulation group therapy (ERGT), schema therapy (ST), and one therapy that includes several aspects of ST and DBT. The mean duration of the psychotherapy was estimated at 54.3 weeks and the sessions were taking place 1-2 times a week. It was proved that psychotherapy not only lowered the psychopathological symptoms in many patients with BPD, but also increased the physical, mental, emotional, as well as social functioning [32].

Ng et al. (2019) performed a study on 102 patients with BPD and presented particular aims that should be earned during treatment [33]. Those include the lowering of the ailment of symptoms that are typical for BPD, the improvement in one's frame of mind, better interpersonal relations, greater self-esteem. The aims that should be earned according to this study are beyond the reduction of the symptoms and involve the aims that are of psychosocial character.

\section{Pharmacotherapy:}

Individualized pharmacotherapy which aims to help specific symptoms in patients with BPD might improve the particular aspects of the clinical picture of a patient. Nevertheless, pharmacotherapy was not proved to be as successful in case of the all of the psychopathological symptoms [34]. Polypragmasy should be avoided or strictly limited. So far it was shown that the introduction of pharmacotherapy as the only way of treatment is not enough to treat patients with BPD. The combination of pharmacotherapy with psychotherapy might improve specific symptoms in patients with BPD, especially aspects that would be very slowly improved or even will not be improved during the application of monotherapy. The major classes of drugs used in BPD are antidepressants, mood stabilizers, antipsychotic drugs (first-, second-, third-generation), as well as opioid antagonists, clonidine, oxy tocin, omega-3 fatty acids [34].

In a study on the supplementation of the omega-3 fatty acids in juveniles with BPD conducted by Amminger et al. (2013), at the beginning, the levels of n-3 PUFA of the erythrocytes were positively correlated with the psychosocial functioning, whereas, they were negatively correlated with the psychopathology [35]. At the end of the study, the level of n-3 PUFA significantly improved the functioning and lowered the psychotic symptoms in comparison to the placebo group. Long-chain n-3 PUFA should be further studied as a potential strategy of BDP treatment primarily in juveniles.

\section{Additional methods of treatment:}

An innovative method of dealing with patients with BPD is a cooperation between a patient and a psychotherapist with the usage of the mobile application 
as a supplement of the dialectical behavioral therapy. Based on the study performed by Helweg-Joergensen et al. (2019) in Denmark, it was proved that long-term monitoring of the progress during the psychotherapy of patients with BPD is a challenging task, therefore, this application was rated as very useful and suitable for the registration of the treatment progress by both patients and psychotherapists [36]. The older users showed lower than younger users need to accept this new technology in the clinical practice.

In the context of the new technologies, specific e-programs that aim to help in the therapy of the patients with BPD are also used. Programs for online work offer a wide spectrum of psychoeducational aspects and a lot of therapeutic exercises. A study performed by Jacob et al. (2018) showed that the symptoms of patients with BPD were much more improved after the application of e-programs during therapy [37]. The program was positively accepted by patients and psychotherapists. It is a potentially useful and safe tool that might support individual schema therapy.

\section{Discussion}

This case report aims to present the life of a person with BPD. The patient who is described in this work tends to take actions very impulsively without the insight into the possible consequences of her decisions. The patient changes her mood very often and quickly, they cannot be even predicted, she tends to present emotional outbursts as well as behaviours that usually lead to conflicts with other people. She has a distorted picture of herself, her aims and preferences, what is more, she feels the constant feeling of the inner emptiness. She presents a tendency for self-destructive behaviours, as well as the trials to attempt suicide. The treatment of patients with BPD is primarily based on the introduction of the psychotherapy. Pharmacological treatment is the only additional method used during the whole therapy. There are also other methods of treatment. It is crucial to avoid the stigmatization of patients with BPD. A significant improvement in the social functioning is obtained by the patient's insight into the nature of the difficulties one's struggling with as well as the maintenance of the cooperation with the psychotherapist.

The diagnosis of borderline personality disorder should always be differentiated with other psychiatric disorders, especially with affective disorders, behaviors related to the use of psychoactive substances, anxiety disorders (especially with post-traumatic stress disorder (PTSD)), as well as schizoaffective disorders and schizophrenia, especially when violent behaviors, delusions, and incomprehensible statements are present [38].
Borderline personality disorder (BPD) and affective bipolar disorders are characterized by the presence of similar symptoms such as impulsiveness, mood inadequacy, suicidal thoughts, self-mutilation, affective dysregulation, or impaired interpersonal relationships, which might constitute a crucial diagnostic difficulty for the clinicians. Moreover, the co-occurrence of the BPD with other psychiatric conditions is quite common in medical practice [39]. One of the major differences is that in patients with BPD, symptoms are usually more severe; besides in such patients, the experienced symptoms are far more frequently correlated with traumatic experiences from childhood. What is crucial, is that BPD and affective disorders usually coexist - 10-20\% of patients with ChAD are diagnosed with coexisting BPD, whereas $20 \%$ of patients with BPD are also diagnosed with ChAD $[40,41]$. According to the NICE Clinical Guidelines, in patients with mood lability and impaired functioning, ChAD diagnosis should be considered at the very beginning of the diagnostic process, afterwards - BPD can be taken into consideration [42]. In cases of BPD, patients more often have a disturbed self-image, their interpersonal relationships are significantly impaired, are characterized by enhanced impulsiveness and the percentage of the suicidal attempts - however, differently to ChAD patients - those are primarily attempts and not committed suicides [43]. Besides, there are major differences regarding the time that concerns mood lability - in BPD patients mood lability usually lasts for several hours or days, whereas in patients with mania - mood lability might last a minimum for one week [44].

Excessive alcohol or other psychoactive substances consumption is observed in approximately $40 \%$ of BPD patients [45]. The co-occurrence of the above-mentioned states constitutes a crucial diagnostic difficulty, which makes it difficult to find the primary etiology of the problem. In clinical practice, it is quite often hard to assess whether particular symptoms are the results of the excessive consumption of specific psychoactive substances without the coexisting BPD, or whether excessive consumption of psychoactive drugs is associated with BPD which is a result of a higher susceptibility for addictions of such patients.

Patients with PTSD present similar symptoms to those that are observed during the course of BPD such as sudden outbursts of anger, a feeling of emptiness, or dissociative symptoms. Another argument that indicates possible diagnostic difficulties of BPD and PTSD is the similar etiology of both of the disorders which is usually the traumatic event that happened in the past. Moreover, those two disorders usually co-exist with one another, which additionally impedes the diagnosis especially during its first stages $[46,47]$. 
The similarity of BPD to schizoaffective disorders or schizophrenia is associated with the fact that patients from both of those groups might present temporary paranoid symptoms, self-harm, and increased suspicion. Nevertheless, patients with BPD are characterized by better general functioning and the absence of negative symptoms.

According to the current state of knowledge, traumatic experiences during childhood and adolescence lead to the neuronal changes that affect the development of abnormal ways of regulating emotions, and thus - to the disturbed personality. The diagnosis of borderline personality disorder is challenging because there is no psychometric tool that can provide a clear diagnosis. BPD remains a continuum in psychiatry and creates one of the major diagnostic difficulties [39].

\section{Conclusions:}

\section{Wstęp}

Osobowość chwiejna emocjonalnie typu borderline (z pogranicza) (borderline personality disorder - BPD) jest poważnym zaburzeniem psychicznym, które charakteryzuje się niestabilnym postrzeganiem siebie, zaburzeniami afektu, powtarzającymi się zachowaniami autodestrukcyjnymi, a także trudnością w tworzeniu relacji interpersonalnych [1]. Dane epidemiologiczne wskazują, że problem zaburzenia osobowości typu borderline dotyczy około 1,7\% społeczeństwa i jest on diagnozowany aż u 15-28\% pacjentów klinik i szpitali psychiatrycznych [2]. Ryzyko rozwoju zaburzenia w ciągu całego życia wynosi 5,9\% [3,4]. Występuje ono $\mathrm{z}$ równą częstością u obu płci [3]. BPD jest również związane z dużego stopnia niepełnosprawnością fizyczną i psychiczną, szczególnie wśród młodych kobiet.

Termin „borderline state” został po raz pierwszy użyty w pracy opublikowanej przez Roberta Knighta w 1953 roku [5]. Dotyczył on osób, które nie mogły być zdiagnozowane jako czysto psychotyczne bądź neurotyczne, ale wykazywały cechy charakterystyczne dla obu tych zaburzeń. W 1978 roku wyróżniono 7 charakterystycznych cech (discriminating criteria) pacjentów określanych mianem „osób z pogranicza”: niewielkie osiągnięcia i brak motywacji, impulsywność, częste myśli samobójcze, zwiększona uczuciowość, łagodne epizody psychotyczne, chęć uspołeczniania się przy okazji zaburzonych relacji międzyludzkich [6]. Publikacja ta stała się filarem pierwszych, oficjalnych kryteriów American Psychiatric Association DSM-III, pozwalających na rozpoznanie zaburzenia osobowości borderline. Obecnie stosowanymi narzędziami do
1. BPD is a psychiatric condition that is a cause of disabilities in many aspects of everyday life.

2. A difficult differential diagnosis leads to the delayed diagnosis and thus - to the delayed start of proper treatment.

3. The therapeutic process of a patient with BPD is primarily based on psychotherapy and personalized treatment.

4. Pharmacological treatment is only additional way of treatment. The major classes of drugs used to treat specific symptoms of the BPD include antidepressants, mood stabilizers, antipsychotic drugs (first-, second-, third-generation), opioid antagonists, clonidine, oxytocin, omega-3 fatty acids.

5. BPD should be differentiated with many other psychiatric conditions - atypical or subclinical psychosis (schizophrenia in particular), affective disorders, and dissocial personality. rozpoznania BPD są kryteria ICD-10 oraz znowelizowane kryteria DSM-V z 2013 roku. ICD-10 rozróżnia dwa podtypy zaburzeń osobowości chwiejnej emocjonalnie (F 60.3): podtyp borderline i podtyp impulsywny [7]. Klasyfikacja DSM-V nie rozróżnia podziału zaburzeń osobowości na podtypy [8]. W ICD-11 zaproponowano podział zaburzeń osobowości w kontekście ich nasilenia na łagodne, umiarkowane lub ciężkie [9].

Zaburzenie borderline wiąże się $\mathrm{z}$ ponad dziesięciokrotnym wzrostem wskaźnika śmiertelności $\mathrm{z}$ powodu samobójstwa $\mathrm{w}$ porównaniu $\mathrm{z}$ populacją ogólną [10]. Charakterystyczną cechą BPD są chroniczne myśli samobójcze [11]. U osób z zaburzeniami nastroju, myśli samobójcze zazwyczaj zanikają przy remisji choroby. Pacjenci z BPD mogą rozważać samobójstwo przez wiele miesięcy bądź lat, a myśli te mogą się nasilać podczas stresujących wydarzeń życiowych. Zaburzenie osobowości typu borderline często współistnieje z innymi zaburzeniami psychicznymi, między innymi z zaburzeniami lękowymi, co stwarza jeszcze większe ryzyko samobójstwa [12].

Etiologia zaburzenia borderline nie jest do końca jasna, przez co definicja zaburzenia była wielokrotnie zmieniana. Uważa się, że za rozwój BPD odpowiedzialna jest interakcja czynników genetycznych oraz środowiskowych [13]. Wyniki badań na bliźniętach potwierdzają rolę genów, szacując dziedziczność BPD na około $40 \%$. Ponadto, coraz większe zainteresowanie budzą zmiany genetyczne osi podwzgórze-przysadkanadnercza HPA (hypothalamic-pituitary-adrenal axis), która odpowiada za psychologiczną i psychofizjologiczną reakcję stresową. Wykazano, że u osób z BPD występują polimorfizmy genu FKBP5 kodującego białko biorące 
udział w regulacji receptorów glukokortykosteroidowych, co wpływa na dysfunkcję osi HPA $[14,15]$. BPD często współwystępuje $\mathrm{z}$ chorobą alkoholową, przy czym nadmierne spożywanie alkoholu indukuje znaczne zmiany w obrębie centralnego oraz obwodowego układu nerwowego [16-19]. Wśród czynników środowiskowych mających znaczenie w patogenezie zaburzenia borderline wymienia się fizyczną przemoc dziecięcą, nadużycia seksualne, czy zaniedbanie w dzieciństwie [20-23]. Znaczenie ma także niski poziom wychowania rodzicielskiego, awersyjne zachowania rodzicielskie oraz bycie świadkiem przemocy domowej wobec partnera [24,25]. Kolejnym interesującym aspektem są zmiany w obrębie ośrodkowego układu nerwowego, obserwowane u pacjentów z rozpoznanym BPD, takie jak obustronna utrata istoty szarej kory oczodołowo-czołowej, czy zmiany w neuronalnych połączeniach przedczołowolimbicznych, które zaburzają modulację struktur układu limbicznego przez regiony kory czołowej [26-28].

Główną formą leczenia zaburzenia jest terapia poznawczo-behawioralna oraz psychodynamiczna, a także terapia oparta na schematach i przeniesieniu. Wspomagająco stosuje się leczenie farmakologiczne: leki przeciwpsychotyczne, leki przeciwdepresyjne oraz leki normotymiczne. Obecnie istnieje więcej dowodów na większą skuteczność psychoterapii nad farmakoterapią. Głównym założeniem leczenia jest poprawa funkcjonowania społecznego. Jest to cel bardzo trudny do osiągnięcia, który stanowi duże wyzwanie dla klinicystów.

\section{Opis przypadku}

Pacjentka, lat 18, panna, bezdzietna, uczennica III klasy Liceum Ogólnokształcącego, pięciokrotnie hospitalizowana psychiatrycznie. Pierwsza hospitalizacja psychiatryczna spowodowana była obniżeniem nastroju i napędu psychomotorycznego, zmianą zachowania, rozdrażnieniem, wystąpieniem agresji słownej oraz utratą apetytu, które były konsekwencją wystąpienia sytuacji urazowej w środowisku rówieśniczym. Pacjentka początkowo została wypisana ze szpitala z rozpoznaniem reakcji na ciężki stres (F 43.2). Kolejne przyjęcie na Oddział Psychiatryczny nastąpiło dziesięć miesięcy później z powodu podjęcia przez pacjentkę próby samobójczej poprzez przyjęcie kilkunastu tabletek paroksetyny, po czym została wypisana z rozpoznaniem specyficznych zaburzeń osobowości (F 60.0). W trakcie kolejnych hospitalizacji $\mathrm{z}$ powodu podejmowania prób samobójczych, postawiono rozpoznanie F 60.8 osobowość kształtująca się nieprawidłowo. Ostatecznie postawiono rozpoznanie F 60.3 - osobowość chwiejna emocjonalnie.

Z wywiadu zebranego $\mathrm{w}$ kierunku stosowania substancji psychoaktywnych i uzależnień pacjentka podaje kilkukrotne stosowanie marihuany, pod wpływem której doświadczała objawów psychotycznych - wypowiadała urojenia prześladowcze. Podaje też, że pali około 10 papierosów dziennie oraz spożywa alkohol średnio raz w tygodniu począwszy od 16 roku życia.

W wywiadzie okołoporodowym - pacjentka urodzona w 27 tygodniu ciąży $\mathrm{z}$ powodu silnego krwawienia z dróg rodnych matki, masa urodzeniowa 1100 g. Wynik w skali Apgar w pierwszej minucie 5 punktów, z powodu braku odruchów, zabarwienia skóry oraz napięcia mięśniowego, w trzeciej minucie otrzymała 7 punktów. Rozwój wczesnodziecięcy przebiegał prawidłowo.

Obciążenie rodzinne w kierunku zaburzeń psychicznych obejmuje zdiagnozowaną depresję u krewnego drugiego stopnia.

\section{Przyczyny hospitalizacji}

Powodem ostatniej hospitalizacji pacjentki były liczne wypowiadane treści suicydalne, dokonywanie samookaleczeń, pobudzenie psychoruchowe, impulsywność, wystąpienie bezsenności oraz zachowań agresywnych. Pacjentka wypowiadała liczne wulgaryzmy, często o charakterze seksualnym oraz groźby względem personelu.

\section{Sytuacja rodzinna}

Pacjentka mieszka $\mathrm{w}$ domu rodzinnym na wsi wraz z rodzicami i dwojgiem młodszego rodzeństwa. Relacje zarówno z matką jak i z ojcem pacjentka określa jako nieodpowiednie i niespełniające jej oczekiwań. W rozmowach indywidualnych wielokrotnie pojawiała się niechęć do obojga rodziców. Siostra pacjentki jest obecnie w okresie dojrzewania, sprawia problemy wychowawcze pod postacią zachowań opozycyjno- buntowniczych i pozostaje pod nadzorem kuratora. Brat jest uległy w stosunku do obojga rodziców. Pacjentka określa relacje $\mathrm{z}$ rodzeństwem jako bardzo dobre, jednak w trakcie hospitalizacji występowały przesłanki ku temu by sądzić, że rywalizuje z młodszą siostrą o uwagę rodziców. Stosunki pomiędzy młodszym bratem i siostrą pacjentka opisywała jako poprawne, natomiast między rodzicami, a młodszym rodzeństwem jako skomplikowane.

Ojciec pacjentki prowadzi własną działalność gospodarczą, matka zajmuje się domem. Rodzice pacjentki są po rozwodzie, jednak mieszkają wspólnie. Nową partnerką ojca jest siostra matki pacjentki, z którą ma on także dzieci, z którymi zarówno pacjentka jak i jej młodsze rodzeństwo utrzymuje kontakty. Z zebranego wywiadu wynika, że rodzice stosują kary cielesne względem wszystkich dzieci. Według ich relacji bardzo zauważalna zmiana w zachowaniu pacjentki pojawiła się rok temu. 
Wcześniejsze funkcjonowanie nie budziło zastrzeżeń.

Pacjentka stopniowo wycofywała się z aktywności, które sprawiały jej przyjemność, przestała udzielać się w przedsięwzięciach szkolnych i tych poza nią. Stopniowo stawała się coraz bardziej wulgarna, agresywna i zaczęła dokonywać samookaleczeń w obrębie obu przedramion. W tym czasie zaczęła palić również papierosy, spożywać alkohol oraz eksperymentować z substancjami psychoaktywnymi, pod wpływem których doświadczała objawów psychotycznych - urojeń prześladowczych. Gwałtowna zmiana zachowania pacjentki na bardziej impulsywne była także związana z wystąpieniem sytuacji urazowej w środowisku rówieśniczym - przyjaciółka z klasy popełniła samobójstwo. Pacjentka podaje osiem podjętych prób samobójczych. Ostatnia próba miała miejsce 11.09.2019 poprzez zażycie kilkunastu tabletek paroksetyny. Kilka miesięcy po zmianie zachowania pacjentka była konsultowana psychiatrycznie w trybie ambulatoryjnym. Pozostawała pod opieką psychoterapeuty, z którym nie chciała współpracować wykazując bierny opór. Po kilku sesjach przerwała terapię.

\section{Sytuacja szkolna}

Pacjentka jest uczennicą III klasy Liceum Ogólnokształcącego. W szkole podstawowej i gimnazjum adaptowała się prawidłowo, była wzorową uczennicą, która czynnie angażowała się w życie szkoły organizując różnego rodzaju przedsięwzięcia. W ciągu swojej edukacji nigdy nie powtarzała klasy. Problemy stopniowo zaczęły narastać wraz z pójściem do liceum. Pacjentka uzyskiwała tam oceny dostateczne i nie nawiązywała nowych znajomości. Jej relacje ograniczały się do trzech osób, które znała jeszcze ze szkoły podstawowej. Z czasem pacjentka zaczęła prezentować zachowania agresywne, które wpłynęły na popadanie w konflikty zarówno z rodzicami, nauczycielami, jak i z rówieśnikami. Zaczęła wagarować i palić marihuanę. Wolny czas spędzała z rodzeństwem i znajomymi, którzy według zebranego wywiadu przedstawiali tendencję do nieprzestrzegania porządku społeczno-obyczajowego.

\section{Badanie psychologiczne}

Minnesocki Wielowymiarowy Inwentarz Osobowości - 2 (MMPI-2) został opublikowany w 1943 roku przez dr Starke Hathwaya i lek. J. Charnleya McKinleya i do dzisiaj pozostaje najpopularniejszą kwestionariuszową metodą badania osobowości [29].

Podczas diagnostyki pacjentka została zbadana Inwentarzem Osobowości. Analiza skal kontrolnych L (43T), F (46T), Fb (94), Fp (70), FBS (69T), K (82T), wskazuje na wyolbrzymianie doświadczanych objawów psychopatologicznych których genezy badana nie jest świadoma. Profil skal klinicznych D (76T), Sc (79T), Pd
(75T), Hy (66T) jest wyraźnie podwyższony. W profilu klinicznym najwyższą wartość osiągnęła skala Sc (79T) co sugeruje, że w samopoczuciu pacjentki dominują stany emocjonalne związane z niepokojem, lękiem oraz napięciem. Prawdopodobna jest izolacja interpersonalna związana $\mathrm{z}$ trudnościami $\mathrm{w}$ nawiązaniu bliskich emocjonalnie relacji zależnościowych. Badana w relacjach z innymi ludźmi przejawia podejrzliwość co do ich intencji, nadmierną wrażliwość, a także obawę przed byciem odrzuconą. Szczególnie cechuje ją uległość oraz poczucie gorszości względem innych. Ponadto badana doświadcza obniżonego nastroju D (76T) ujawnia tendencję do zamartwiania się oraz ruminacji myśli dotyczących przeszłych wydarzeń, a także zdradza lękową wizję swojej przyszłości. Na podstawie wyników w skali Pd (75T) można wnioskować, iż pacjentka wykazuje tendencję do impulsywnych zachowań oraz tłumienia emocji tj.; złość, wrogość oraz agresja, a także bunt wobec autorytetów. Ponadto, pomniejsza znaczenie swoich trudności o charakterze emocjonalnym oraz wykazuje brak realizmu w ocenie doświadczanych sytuacji. Analiza wyników skali klinicznej Hy (73T) wskazuje na brak wglądu w istotę i naturę swoich trudności. Możliwa jest również skłonność do reagowania objawami somatycznymi na nierozwiązane problemy natury psychologicznej. Biorąc pod uwagę powyższe, uzyskany w badaniu obraz kliniczny wskazuje na osobowościowy charakter doświadczanych objawów psychopatologicznych o cechach osobowości chwiejno emocjonalnej.

\section{Konsultacja neurologiczna}

W czasie leczenia ambulatoryjnego pacjentka przyjmowała: pregabalinę, trazodon, wenlafaksynę, kwetiapinę, klorazepan i pernazynę. Podczas hospitalizacji odmówiła przyjmowania wszystkich zleconych leków, mimo poinformowania przez lekarza o możliwych konsekwencjach dla zdrowia i życia. U pacjentki wystąpił zespół odstawienny pod postacią niepokoju, splątania, drażliwości, zawrotów głowy i przejściowych zaburzeń świadomości. Z powodu powyższej sytuacji, wynik pierwszego badania EEG był niemiarodajny i nie nadawał się do interpretacji. W kolejnym badaniu EEG zapis nieprawidłowy. Wystąpiły nasilające się pod wpływem hiperwentylacji zmiany uogólnione lub ograniczone do okolic skroniowych - zmienne co do strony (nieznacznie częstsze po stronie lewej), w postaci grup fal wolnych theta-delta, lub salw wolnych i ostrych o cechach napadowych. Czynność podstawowa o cechach dezorganizacji i niewielkiego zwolnienia. W badaniu MRI obraz prawidłowy. Neurolog zalecił kontrolę w poradni neurologicznej oraz wykonanie kontrolnego badania EEG w ciągu 6 miesięcy od czasu wypisania pacjentki z oddziału. 


\section{Przebieg hospitalizacji}

W dniu przyjęcia do szpitala pacjentka usiłowała dokonać samobójstwa poprzez powieszenie na sznurówkach od butów. Próbę udaremniono dzięki interwencji personelu, wobec którego pacjentka była agresywna zarówno słownie jak i fizycznie. W Oddziale pacjentka początkowo była niedostosowana w zachowaniu, impulsywna, pobudzona psychoruchowo, drażliwa, w obniżonym nastroju. Za przeżywane trudności obwiniała otoczenie, czuła się nieszczęśliwa i nierozumiana, wypowiadała nasilone treści samobójcze. Miała tendencje do zachowań agresywnych i autoagresywnych. Dokonywała samookaleczeń w obrębie lewego przedramienia; $\mathrm{z}$ powodu takich zachowań była kilkukrotnie unieruchamiana pasami bezpieczeństwa. Kilkukrotnie łamała regulamin Oddziału paląc papierosy na swojej sali. Z czasem jednak współpraca z pacjentką stopniowo się poprawiła. Podczas rozmów indywidualnych zaczęła utrzymywać kontakt wzrokowy. Pozostawała w rzeczowym, ubogotreściowym kontakcie werbalnym. Zaczęła nawiązywać prawidłowe relacje rówieśnicze, brać udział w spotkaniach społeczności, zajęciach ruchowych i edukacyjnych. Poprzez prowadzoną psychoterapię indywidualną oraz grupową uzyskano poprawę funkcjonowania w środowisku rówieśniczym. Pacjentka przejawiała częściowy wgląd w naturę przeżywanych trudności. Bardzo dobrą poprawę stanu psychicznego uzyskano poprzez oddziaływania psychoterapeutyczne poprowadzone w nurcie psychodynamicznym, jak i zastosowaniu elementów psychoterapii psychoanalitycznej. Dla utrzymania osiągniętego sukcesu terapeutycznego niezbędna jest kontynuacja psychoterapii indywidualnej oraz rodzinnej.

\section{Psychoterapia}

Na podstawie wyników badań naukowych, obecnie żadna ze strategii terapeutycznych nie ma wyższości w leczeniu osób z BPD. Zaburzenia osobowości typu borderline są wysoce niejednorodne, dlatego terapia powinna zostać dobrana dla konkretnego pacjenta w sposób indywidualny. Według Keefe et al. (2020), na podstawie badania przeprowadzonego na 156 osobach z BPD poddanych rocznej terapii dialektycznobehawioralnej i terapii psychodynamicznej wykazano, że indywidualne cechy i potrzeby pacjenta wpływają na stopień, w jakim reagują one na dwa sposoby leczenia [30]. Dowiedziono, że konieczne są dalsze badania nad spersonalizowaną medycyną w BPD.

Prowadzenie psychoterapii z osobą z zaburzeniem osobowości typu borderline jest niezwykle wymagające dla psychoterapeuty. Putrino et al. (2019) zaobserwował, że psychoterapeuci odczuwają u siebie emocje związane z rozregulowaniem u pacjentów z BPD [31]. Terapeuci mogą odzwierciedlać wewnętrzne doświadczenia swoich pacjentów, dlatego też muszą być świadomi swoich własnych reakcji emocjonalnych, ponieważ może mieć to wpływ na relacje $\mathrm{z}$ pacjentem oraz wyniki terapii. W związku z powyższym, psychoterapeutom rekomenduje się trening uważności, który może być skutecznym narzędziem w rozwijaniu samoregulacji zamiast unikania albo nadmiernej identy fikacji z cierpieniem emocjonalnym swoich pacjentów.

$\mathrm{Na}$ podstawie metaanalizy „Efekt psychoterapii na jakość życia u osób z BPD” uwzględniającej 1370 pacjentów, gdzie średnia wieku wynosiła 31.2 lata i 86.8\% było kobietami, Chakhssi et al. (2019) wykazali skuteczność następujących psychoterapii: dialektyczna terapia behawioralna (DBT; $n=4)$, terapia oparta na mentalizacji (MBT; $\mathrm{n}=3$ ), trening systemów przewidywania emocji i rozwiązywania problemów (STEPPS; $\mathrm{n}=2$ ), a w pozostałych pięciu badaniach terapia kognitywna (CT), terapia poznawczo-behawioralna (CBT), terapia grupowa regulacji emocji (ERGT), terapia schematem (ST) oraz jedna modalność psychoterapii łącząca elementy ST i DBT. Średnia długość psychoterapii wynosiła 54.3 tygodnia, a sesje odbywały się 1-2 razy $\mathrm{w}$ tygodniu. Dowiedziono, że psychoterapia nie tylko zmniejsza objawy psychopatologiczne u osób z BPD, ale także powoduje wzrost $\mathrm{w}$ funkcjonowaniu fizycznym, psychicznym, emocjonalnym i społecznym [32].

$\mathrm{Ng}$ et al. (2019) przeprowadziła badanie na 102 osobach z zaburzeniem osobowości typu borderline i wyłoniła cele, które osoby te chcą osiągnąć podczas leczenia [33]. Jest to: zmniejszenie dolegliwości objawów, które są typowe dla tego zaburzenia osobowości, poprawa samopoczucia, lepsze relacje interpersonalne, większe poczucie własnej wartości. Osobiście znaczące cele leczenia w tym badaniu wykraczają poza redukcję objawów i obejmują cele o charakterze psychospołecznym.

\section{Farmakoterapia}

Zindywidualizowana farmakoterapia, nastawiona na konkretne objawy u osób z BPD może poprawić odpowiednie aspekty obrazu klinicznego. Jednakże nie wykazano żadnej skutecznej farmakoterapii, która swoim zasięgiem obejmowałaby całokształt objawów psychopatologicznych [34]. Polipragmazji należy unikać lub ściśle ją ograniczać. Do tej pory wykazano, że zastosowanie farmakoterapii jako jedynej metody leczenia, nie jest wystarczająca do leczenia zaburzenia. Łączenie farmakoterapii z psychoterapią może poprawić określone objawy w BPD, przede wszystkim te aspekty, które szczególnie wolno lub wcale nie ulegają poprawie podczas stosowania monoterapii. Główne klasy leków używane w BPD to: leki przeciwdepresyjne, stabilizatory nastroju, leki przeciwpsychotyczne pierwszej, drugiej i 
trzeciej generacji oraz antagoniści opioidów, klonidyna, oksytocyna, kwasy tłuszczowe omega - 3 [34].

W badaniu na temat suplementacji kwasami tłuszczowymi omega 3 u młodzieży z BPD przeprowadzonym przez Amminger et al. (2013) na początku poziomy n-3 PUFA erytrocytów korelowały dodatnio z funkcjonowaniem psychospołecznym, a ujemnie z psychopatologią [35]. Pod koniec badania n-3 PUFA znacząco poprawiły funkcjonowanie i zmniejszyły objawy psychiczne w porównaniu z placebo. Długołańcuchowe n-3 PUFA powinny być dalej badane jako potencjalna strategia leczenia u młodych ludzi z BPD.

\section{Wspomagające metody leczenia}

Innowacyjną metodą pracy z osobami dotkniętymi BPD jest współpraca pacjenta i psychoterapeuty poprzez aplikację mobilną jako uzupełnienie dialektycznej terapii behawioralnej. $\mathrm{Na}$ podstawie padania przeprowadzonego w Danii przez HelwegJoergensen et al. (2019), dowiedziono, że długoterminowe monitorowanie postępów podczas psychoterapii osób z BPD stanowi wyzwanie, dlatego aplikacja została oceniona jako przydatna i odpowiednia do rejestrowania progresu w leczeniu zarówno przez pacjentów jak i psychoterapeutów [36]. Starsi użytkownicy wykazywali, mniejsze niż młodsi, pragnienie do zaakceptowania nowej technologii w praktyce klinicznej.

W kontekście nowoczesnych technologii, zastosowanie mają także e-programy przeznaczone do pracy terapeutycznej $\mathrm{z}$ osobami $\mathrm{z}$ zaburzeniami osobowości typu borderline. Program do pracy online oferuje szeroką treść psychoedukacyjną i wiele ćwiczeń terapeutycznych. Badanie przeprowadzone przez Jacob et al. (2018) wykazało, że objawy u osób z BPD uległy znacznej poprawie podczas wspierania psychoterapii e-programami [37]. Program został pozytywnie przyjęty zarówno przez pacjentów jak i psychoterapeutów. Jest potencjalnie pomocnym i bezpiecznym narzędziem, które może wspierać indywidualną terapię opartą na schemacie.

\section{Dyskusja}

Przedstawiony opis przypadku w pełni oddaje linię życiową osób z zaburzeniami osobowości typu borderline. Opisana pacjentka ma tendencję do podejmowania impulsywnych działań bez przewidywania konsekwencji swoich decyzji. Przejawia częste zmiany nastroju, których nie da się przewidzieć oraz skłonność do wybuchów emocjonalnych i zachowań, które prowadzą do konfliktów z innymi. Posiada zaburzony obraz samej siebie, swoich celów i preferencji, przy czym towarzyszy jej stałe uczucie wewnętrznej pustki. Prezentuje tendencję do działań samouszkadzających, jak i podejmowania prób samobójczych. Leczenie osób z zaburzeniem osobowości typu borderline opiera się głównie na podjęciu psychoterapii. Oddziaływania farmakologiczne odgrywają rolę wspierającą. Istnieją także inne wspomagające metody leczenia. Istotne jest, żeby nie stygmatyzować osób z zaburzeniem osobowości typu borderline. Znaczącą poprawę w funkcjonowaniu społecznym uzyskuje się poprzez uzyskanie wglądu w naturę przeżywanych trudności i utrzymywanie stałej współpracy z psychoterapeutą.

Rozpoznanie zaburzenia osobowości typu borderline powinno być zawsze różnicowane z innymi zaburzeniami psychicznymi, przede wszystkim $\mathrm{z}$ zaburzeniami afektywnymi, zachowaniami związanymi z używaniem substancji psychoaktywnych, zaburzeniami lękowymi (przede wszystkim z zaburzeniami stresu pourazowego (PTSD)), a także zaburzeniami schizoafektywnymi i schizofrenią, szczególnie wtedy, gdy występują zachowania gwałtowne, urojenia i niezrozumiałe wypowiedzi [38].

Zaburzenie osobowości typu borderline oraz zaburzenia afektywne dwubiegunowe charakteryzują się występowaniem podobnych objawów takich jak impulsywność, nieadekwatność nastroju, myśli samobójcze, dokonywanie samookaleczeń, deregulacja afektywna czy zaburzone relacje interpersonalne, co może stanowić poważny problem diagnostyczny dla klinicystów. Co więcej, współwystępowanie BPD z innymi zaburzeniami jest zjawiskiem dość typowym w praktyce lekarskiej [39]. Jedną z istotnych różnic jest większe nasilenie objawów w przypadku zaburzeń osobowości typu borderline; ponadto, w tym przypadku, występujące symptomy są o wiele częściej skorelowane w przykrymi doświadczeniami z dzieciństwa. Co istotne, zaburzenia osobowości typu borderline oraz zaburzenia afektywne często współwystępują ze sobą - u około 10-20\% chorych z ChAD rozpoznaje się współistniejące BPD, natomiast u około 20\% pacjentów z BPD rozpoznaje się ChAD [40,41]. Zgodnie z wytycznymi NICE Clinical Guidelines, u pacjentów ze zmiennym nastrojem oraz zaburzonym funkcjonowaniem, na samym początku należy rozważyć diagnozę ChAD, a dopiero później - BPD [42]. W przy padku BPD, pacjenci o wiele częściej mają zaburzony obraz samego siebie, ich stosunki interpersonalne są znacznie zaburzone, cechuje ich większa impulsywność oraz odsetek prób samobójczych - aczkolwiek odmiennie niż w przypadku pacjentów z ChAD - są to w większości próby, a nie samobójstwa dokonane [43]. Ponadto, występują różnice w przypadku czasu utrzymujących się zmian nastroju - u pacjentów z BPD zmienność nastroju najczęściej dotyczy kilku godzin czy dni - w przypadku manii jest to minimum tydzień [44].

Nadmierne spożywanie alkoholu czy też innych substancji psychoaktywnych jest obserwowane u około 
40\% pacjentów z BPD [45]. Współwystępowanie tych dwóch jednostek stanowi poważne wyzwanie diagnostyczne, które często utrudnia znalezienie pierwotnej etiologii problemu. W praktyce klinicznej dość częstym zjawiskiem jest niemożność stwierdzenia czy poszczególne objawy są wynikiem nadmiernego spożycia substancji psychoaktywnych bez współistniejącego BPD, czy też nadmierne spożycie tych substancji współwystępuje z tym schorzeniem i jest wyłącznie wynikiem podatności tej grupy pacjentów na nadmierne spożywanie takich substancji.

Pacjenci z PTSD prezentują podobne objawy do tych, które występują w przebiegu BPD, takie jak nagłe wybuchy złości, uczucie pustki czy objawy dysocjacyjne. Kolejnym argumentem, który wskazuje na możliwe trudności diagnostyczne $w$ przypadku BPD i PTSD jest podobne podłoże etiologiczne, jakim w obydwu przypadkach jest zjawisko traumatyczne występujące w przeszłości. Co więcej, obydwa schorzenia bardzo często współwystępują ze sobą, co dodatkowo utrudnia diagnostykę przede wszystkim na jej wczesnych etapach $[46,47]$.

Podobieństwo BPD do zaburzeń schizoafektywnych oraz schizofrenii wynika z możliwości występowania u tych pacjentów przejściowych objawów paranoidalnych, samouszkodzeń oraz nasilonej podejrzliwości. Niemniej jednak, pacjenci z BPD charakteryzują się lepszym ogólnym funkcjonowaniem oraz brakiem objawów negatywnych.

Według obecnego stanu wiedzy, doświadczenia traumatyczne $\mathrm{w}$ okresie dzieciństwa i adolescencji prowadzą do zmian neuronalnych, które mają wpływ na kształtowanie się nieprawidłowych sposobów regulacji emocji, a co za tym idzie zaburzonej osobowości. Diagnostyka zaburzenia osobowości typu borderline stanowi wyzwanie, ponieważ nie istnieje żadne narzędzie psychometryczne, dzięki któremu można by było jednoznacznie postawić rozpoznanie. Zaburzenie osobowości z pogranicza stanowi w psychiatrii continuum i stwarza duże trudności diagnostyczne [48].

\section{Wnioski}

1. Borderline personality disorder (BPD) jest poważnym zaburzeniem psychicznym, które jest przyczyną niepełnosprawności w wielu aspektach życia codziennego.

2. Trudna diagnostyka różnicowa prowadzi do późnego rozpoznania i w związku z tym do opóźnionego rozpoczęcia leczenia.

3. Proces terapeutyczny osoby $\mathrm{z}$ zaburzeniem osobowości typu borderline opiera się głównie na psychoterapii i personalizacji leczenia.

4. Leczenie farmakologiczne odgrywa rolę wspierającą. Główne klasy leków używane w BPD to: leki przeciwdepresyjne, stabilizatory nastroju, leki przeciwpsychotyczne pierwszej, drugiej i trzeciej generacji oraz antagoniści opioidów, klonidyna, oksytocyna, kwasy tłuszczowe omega -3 .

5. Osobowość z pogranicza należy różnicować z wieloma zaburzeniami psychicznymi nietypowym lub subklinicznym przebiegiem psychozy (w szczególności schizofrenii), zaburzeniami afektywnymi oraz osobowością dyssocjalną.

\section{Conflict of interest}

The authors have declared no conflict of interest.

\section{References:}

1. Lieb K, Zanarini MC, Schmahl C, Linehan MM, Bohus M. Borderline personality disorder. Lancet, 2004; 364: 453-461.

2. Gunderson JG, Herpertz SC, Skodol AE, Torgersen S, Zanarini MC Borderline personality disorder. Nature Reviews Disease Primers, 2004; 24;4:18029.

3. Grant BF, Chou SP, Goldstein RB, Huang B, Stinson FS, Saha TD, et al. Prevalence, correlates, disability, and comorbidity of DSM-IV borderline personality disorder: results from the Wave 2 National Epidemiologic Survey on Alcohol and Related Conditions. J Clin Psychiatry 2008; 69:533.

4. Borderline personality disorder. Nat Rev Dis Primers, 2018; 24;4:1830. https://doi.org/10.1038/nrdp.2018.30

5. Knight RP. Borderline states. Bull Menninger Clin, 1953; 17:1-12.

6. APA PsycNet [Internet]. American Psychological Association. American Psychological Association; [cytowana 22 lipca 2020]. Dostępna z: https://psycnet.apa.org/record/1979-23763-001

7. World Health Organization. International Classification of Diseases. 11th ed. World Health Organization; Geneva, Switzerland: 2018.

8. American Psychiatric Association. DSM-5. Diagnostic and Statistical Manual of Mental Disorders, 5th edn. Washington, DC, USA: American Psychiatric Association, 2013.

9. Gaebel W, Zielasek J, Reed G. Mental and Behavioural Disorders in the ICD-11: Concepts, Methodologies, and Current Status. Psychiatria Polska, 2017; 51(2):169-95.

10. Chesney E, Goodwin GM, Fazel S. Risks of all-cause and suicide mortality in mental disorders: a meta-review. World Psychiatry, 2014; 13(2):153-160.

11. Paris J. Suicidality in Borderline Personality Disorder. Medicina (Kaunas), 2019; 55(6):223.

12. Quenneville AF, Kalogeropoulou E, Küng AL, Hasler R, Nicastro R, Prada P, Perroud N (2019). Childhood maltreatment, anxiety disorders and outcome in Borderline Personality Disorder. Psychiatry Research, 2020; 284:112688.

13. Amad A, Ramoz N, Thomas P, Jardri R, Gorwood P. Genetics of borderline personality disorder: Systematic review and proposal of an integrative model. Neuroscience \& Biobehavioral Reviews, 2014; 40, 6-19.

14. Martín-Blanco A, Ferrer M, Soler J, Arranz MJ, Vega D, Calvo N, et al. The role of hypothalamus-pituitary-adrenal genes and childhood trauma in borderline personality disorder. Eur. Arch. Psychiatry Clin, 2016; 266(4): 307-316.

15. Amad, A, Ramoz, N, Peyre, H, Thomas, P, \& Gorwood, P. FKBP5 
gene variants and borderline personality disorder. Journal of Affective Disorders, 2019; 248: 26-28.

16. Helle A, Watts AL, Trull TJ, Sher KJ. Alcohol Use Disorder and Antisocial and Borderline Personality Disorders. Alcohol Research: Current Reviews, 2019; 40(1).

17. Baj J, Teresiński G, Buszewicz G, Sitarz E, Forma A, Karakuła $\mathrm{K}$, et al. Magnesium, Calcium, Potassium, Sodium, Phosphorus, Selenium, Zinc, and Chromium Levels in Alcohol Use Disorder: A Review. Journal of Clinical Medicine, 2020; 9(6): 1901.

18. Grochowski C, Blicharska E, Bogucki J, Proch J, Mierzwińska A, Baj J, et al. Increased Aluminum Content in Certain Brain Structures is Correlated with Higher Silicon Concentration in Alcoholic Use Disorder. Molecules, 2019; 24(9): 1721.

19. Grochowski C, Blicharska E, Baj J, Mierzwińska A, Brzozowska K, Forma A, et al. Serum iron, Magnesium, Copper, and Manganese Levels in Alcoholism: A Systematic Review. Molecules, 2019; 24(7): 1361.

20. Johnson, JG, Cohen, P, Brown, J, Smailes, EM, Bernstein, DP. Childhood maltreatment increases risk for personality disorders during early adulthood. Arch. Gen. Psychiatry, 1999; 56(7): 600-606.

21. Hengartner MP, Ajdacic-Gross V, Rodgers S, Müller M, Rössler W. Childhood adversity in association with personality disorder dimensions: new findings in an old debate. Eur. Psychiatry, 2013; 28: 476-482.

22. Zanarini MC, Williams AA, Lewis RE, Reich RB, Vera SC, Marino MF, et al. Reported pathological childhood experiences associated with the development of borderline personality disorder. Am. J. Psychiatry, 1997; 154: 1101-1106.

23. Afifi TO, Mather A, Boman J, Fleisher W, Enns MW, Macmillan $\mathrm{H}$, et al. Childhood adversity and personality disorders: results from a nationally representative population-based study. J. Psychiatr. Res, 2011; 45: 814-822.

24. Johnson JG, Cohen P, Chen H, Kasen S, Brook JS. Parenting behaviors associated with risk for offspring personality disorder during adulthood. Arch. Gen. Psychiatry, 2006; 63: 579.

25. Sharp C, Vanwoerden S, Jouriles EN, Godfrey DA, Babcock J, McLaren V, et al. Exposure to interparental intimate partner violence and the development of borderline features in adolescents. Child Abuse Negl, 2020; 12;103: 104448.

26. Nenadić I, Voss A, Besteher B, Langbein K, Gaser C. Brain structure and symptom dimensions in borderline personality disorder. European Psychiatry, 2020; 63(1): E9.

27. Grottaroli M, Delvecchio G, Bressi C, Moltrasio C, Soares JC, Brambilla P. Microstructural white matter alterations in borderline personality disorder: A minireview. J Affect Disord, 2020; $1 ; 264: 249-255$.

28. Davies G, Hayward M, Evans S, Mason O. A systematic review of structural MRI investigations within borderline personality disorder: Identification of key psychological variables of interest going forward. Psychiatry Res, 2020; 13;286: 112864.

29. Cyranka K, Rutkowski K, Mielimąka M, Sobański J, SmiatekMazgaj B, Klasa K, et al. Changes in personality functioning as a result of group psychotherapy with elements of individual psychotherapy in persons with neurotic and personality disorders - MMPI-2. Psychiatria Polska, 2016; 50(1): 105-26.

30. Keefe JR, Kim TT, Derubeis RJ, Streiner DL, Links PS, Mcmain SF. Treatment selection in borderline personality disorder between dialectical behavior therapy and psychodynamic psychiatric management. Psychological Medicine, 2020; 24: 1-9.

31. Putrino N, Casari L, Mesurado B, Etchevers M. Psychotherapists emotional and physiological reactions toward patients with either borderline personality disorder or depression. Psychotherapy Research, 2019; 11: 1-8.
32. Chakhssi F, Zoet JM, Oostendorp JM, Noordzij ML, SommersSpijkerman M. Effect of Psychotherapy for Borderline Personality Disorder on Quality of Life: A Systematic Review and Meta-Analysis. Journal of Personality Disorders, 2019; 1-15.

33. Ng FY, Carter PE, Bourke ME, Grenyer BF. What Do Individuals With Borderline Personality Disorder Want From Treatment? A Study of Self-generated Treatment and Recovery Goals. Journal of Psychiatric Practice, 2019; 25(2): 148-55.

34. Bozzatello P, Rocca P, Rosa MLD, Bellino S. Current and emerging medications for borderline personality disorder: is pharmacotherapy alone enough? Expert Opinion on Pharmacotherapy, 2019; 21(1): 47-61.

35. Amminger GP, Chanen AM, Ohmann S, Klier CM, Mossaheb N, Bechdolf A, et al. Omega-3 Fatty Acid Supplementation in Adolescents with Borderline Personality Disorder and UltraHigh Risk Criteria for Psychosis: A Post Hoc Subgroup Analysis of a Double-Blind, Randomized Controlled Trial. The Canadian Journal of Psychiatry, 2013; 58(7): 402-8.

36. Helweg-Joergensen S, Schmidt T, Lichtenstein MB, Pedersen SS. Using a Mobile Diary App in the Treatment of Borderline Personality Disorder: Mixed Methods Feasibility Study. JMIR Formative Research, 2019; 3(3).

37. Jacob GA, Hauer A, Köhne S, Assmann N, Schaich A, Schweiger U, et al. A Schema Therapy-Based eHealth Program for Patients with Borderline Personality Disorder (priovi): Naturalistic Single-Arm Observational Study. JMIR Mental Health, 2018; 5(4).

38. Cichoń L, Janas-Kozik M, Siwiec A, Rybakowski J. Clinical picture and treatment of bipolar affective disorder in children and adolescents. Psychiatria Polska, 2020; 54(1): 35-50.

39. Emmelkamp PMG, Kamphuis JH. Personality disorders. Psychology Press/Taylor \& Francis, Hove/New York 2007.

40. Zimmerman $M$, Morgan TA. The relationship between borderline personality disorder and bipolar disorder. Dialogues Clin Neuro-sci, 2013; 15:155-169.

41. Gorostowicz A, Siwek M. Trudności w diagnostyce choroby afektywnej dwubiegunowej. Psychiatr Psychol Klin, 2018; 18(1):61-73.

42. Bipolar disorder and its diagnosis. In: National Collaborating Centre for Mental Health (UK): Bipolar Disorder: The Management of Bipo- lar Disorder in Adults, Children and Adolescents, in Primary and Secondary Care. NICE Clinical Guidelines, No. 38. British Psycho- logical Society, Leicester 2006.

43. Bassett D: Borderline personality disorder and bipolar affective disor- der. Spectra or spectre? A review. Aust N Z J Psychiatry, 2012;46: 327-339.

44. Popiel A. Zaburzenia osobowości. Z pogranicza - wyzwanie terapeutyczne. Akademia „Psychiatrii”, 2011; 8(2):64-78.

45. Cerullo MA, Strakowski SM. The prevalence and significance of substance use disorders in bipolar type I and II disorder. Subst Abuse Treat Prev Policy, 2007; 1;2:29.

46. Masland SR, Cummings MH, Null KE, Woynowskie KM, Choi-Kain LW. Changes in post-traumatic stress disorder symptoms during residential treatment for borderline personality disorder: a longitudinal cross-lagged study. Borderline Personal Disord Emot Dysregul, 2019; 6;6:15.

47. Cloitre M, Garvert DW, Weiss B, Carlson EB, Bryant RA. Distinguishing PTSD, Complex PTSD, and Borderline Personality Disorder: A latent class analysis. Eur J Psychotraumatol, 2014; 15;5.

48. Pastuszak A. Emotion regulation in borderline personality disorder - actual research directions. Psychiatria Polska, 2012; 46(3): 401-408 


\section{Corresponding author}

Elżbieta Sitarz

I Department of Psychiatry, Psychotherapy and

Early Intervention, Medical University of Lublin,

Gluska Street 1, 20-439 Lublin, Poland

e-mail: e.sitarz@hotmail.com

Otrzymano: 21.07 .2020

Zrecenzowano: 27.07.2020, 04.08.2020,22.08.2020

Przyjęto do druku: 25.08.2020 